UDC 61-617.582.5

DOI: $10.15587 / 2519-4798.2020 .209143$

\title{
STUDY OF THE LACTOSE INTOLERANCE GENETIC ASPECTS AMONG THE POPULATION AND PATIENTS WITH HIP FRACTURE IN EASTERN UKRAINE
}

\author{
O. Fedota, V. Babalian, V. Borozenets, N. Puzik
}

Близько 75 \% світового населення втрачає здатність до толерантності до лактози в зрілому віці. Вивчення толерантності до лактози (ЛТ) або персистентності лактази (ЛП) в українців є необхідним для виявлення зв 'язку цієї ознаки з мультифакторіальними патологіями, формування груп ризику та розвитку харчової культури.

Метою дослідження була оцінка генетичних аспектів дефіџฺту лактози серед населення та його зв'язок з патологіями людини на прикладі перелому стегна.

Матеріал та методи: Фенотип непереносимості лактози був виявлений у 9, 7 \% украӥнців, а стійкість до лактози - 69,4%. У групі хворих з переломами проксимальної стегнової кістки лезними частотами були: $13910 T-0,34,13910 C-0,66,22018 A-0,35,22018 G-0,65$. Розподіл генотипів становив 0\%: 67,6\%: 32,4\% для ТT:CT:CC та 2,9\%: 64,7\%: 32,4\%, для AA:GA:GG. Відхилення від рівноваги Харді-Вайнберга не спостерігалось.

Результати: В результаті аналізу генотипів для обох SNP було встановлено співвідношення CTAA:CTGA: CCGA:CCGG - 2,9\%: 61,7\%: 2,9\%: 32,5\%. Було оцінено нерівновагу за зчепленням, $D$ ' $\left(r^{2}\right)$ для аналізованих SNP склав 0,209 (0,554). У половини паціснтів був остеопороз або остеопенія (n=50,0\%), але у пацієнтів з генотипом ТТАА ичих патологій не виявлено. Параметри МЩК хворих з генотипом СТGА склали

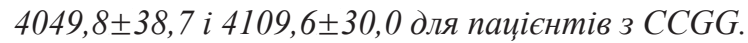

Висновки: Усі пацієнти з остеопорозом мали генотип СТGА, середне значення МПК становило

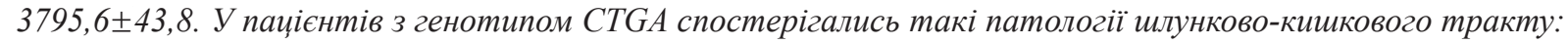
гастрит (33,3\%), виразкова хвороба (9,5\%), виразка дванадиятипалої кишки (9,5\%), рак шлунка (9,5\%). Гетерозиготні генотипи значно збільиують ризик розвитку илунково-кишкової патології у пацієнтів 3 переломами проксимальної стегнової кістки в п'ять разів

Ключові слова: стійкість лактази, непереносимість лактози, переломи проксимального відділу стегна, остеопороз, генотипи, мінеральна щільність кісток

Copyright $(\odot$ 2020, O. Fedota, V. Babalian, V. Borozenets, N. Puzik.

This is an open access article under the CC BY license (http://creativecommons.org/licenses/by/4.0).

\section{Introduction}

Lactose tolerance (LT) or lactase persistence (LP) is an example of selection-based evolutionary change in humans from milk-drinking cultures. Approximately $75 \%$ of the world's population loses this ability before adulthood, while others can digest lactose during all life. The geographic distribution of LP matches the distribution of dairy farming. The highest frequencies are observed in North Western and Northern Europe [1]. The prevalence of lactose intolerance (LI) is lowest in populations with a long history of dependence on unfermented milk products as an important food source [2].

In European Caucasian populations 2 SNPs 13910C-T (rs4988235) and 22018G-A (rs182549) in the MCM6 gene, that has influence on the lactase gene $\mathrm{LCT}$, are regulating lactose tolerance and hypolactasia [3].

The studies on the relationship of lactose deficiency and pathology presented in the literature and discussed are ambiguous. It was shown that intake of milk and dairy products was associated with a neutral or reduced risk of type 2 diabetes and a reduced risk of cardiovascular disease, particularly stroke, risk of lung, breast and ovarian cancers [4].
On the other hand, European lactase regulation genotypes show evidence of relation with increase in body weight [5], lipid pathway [6], abdominal obesity, overweight/obesity, obesity-related variables [7], cardiovascular diseases [8] in different ethnic groups.

Polymorphisms described are associated with multifactorial diseases such as osteoporosis, with calcium metabolism, differences in serum calcium levels and calcium intake [9]. The relation of LI with bone density and the risk for fractures and osteoporosis is one of the major debated issues regarding lactose. It is important to clarify the genetic component of pathology that represented by a number of genes for osteoporosis susceptibility [10]. Osteoporosis as a multifactorial disorder has such risk factors as a number of diseases or treatments, including alcohol abuse, anorexia, hyperthyroidism, kidney disease, and surgical removal of the ovaries, smoking and low physical activity [11]. Osteoporosis has been recognized as one of the major diseases affecting individuals globally, including pregnant and breastfeeding women [12].

According to OECD-FAO Agricultural Outlook 2016-2025, Ukraine ranked in the Top 10 the largest producers of fresh dairy products with a volume of 
8 million tones. Thus, Ukraine has significant consumption of fresh dairy products.

The aim of our study was to evaluate the genetic aspects of lactose deficiency in population and its relation with human pathologies on the example of a hip fracture.

\section{Materials and methods}

Population study to assess the trait prevalence included persons living in Eastern Ukraine aged from 20 to 79 years $(n=620)$. Informed consent was obtained from study participants and their relatives. The population sample was divided into groups with an age interval of 10 years.

To investigate the relationship between lactase deficiency phenotype, genotype and pathologies, a sample of patients with bone pathologies $(n=34)$ was studied. The sample was randomly generated for the trait of lactose intolerance. Patients were hospitalized from 2017-2018 in trauma department of Communal enterprise of health care «Kharkiv clinical multy-field hospital No. 17 of plant named by Malyshev» with fractures of the proximal femur, coxarthrosis. Patients aged 29-86, average age 64.0 2.7 , were examined by internal medicine specialist. Fibrogastroscopy and blood analysis were performed according to the local protocol of orthopedics clinic. Bone mineral density (BMD) of patients was estimated by ultrasonic densitometry (Sunlight Omni 7000 "Sunlight Medical Ltd., Israel). Genotyping of SNPs rs4988235 (13910C-T) and rs182549 (22018G-A) was made by PCR-RFLP, using primer pairs [13] and restriction endonucleases $B S m F I$ and HhaI (ThermoFisher Scientific, USA).

The odds ratio and confidence interval were calculated. The linkage disequilibrium (LD) was estimated by D', $r^{2}$. Exogamy degree scale was measured from 1 - parentage originated from one settlement to 4 - interethnic marriage. Statistical analysis was performed with the Shapiro-Wilk and Kolmogorov-Smirnov tests for normality and hypotheses - criteria $\mathrm{t}$ and $\chi^{2}$, U-test. The deviation of allele frequencies from Hardy-Weinberg equilibrium was tested using Pearson's chi-squared test. The relationship between traits was estimated by the Spearman correlation analysis.

Ethical considerations. The study conforms to the Helsinki Declaration (1997), the Convention on Europe on Human Rights and Biomedicine (1997), the International Code of Medical Ethics (1983), ICHGSP (2002), and national legislation on domestic law Bioethics of Kharkiv Medical Academy of Postgraduate Education (protocol No. 5 dated 12.11.2019).

\section{Results}

The analysis of the results obtained in the present population study indicated that lactose persistence phenotype was found in $69.4 \%$ of patients studied and lactase intolerance - in approximately $9.7 \%$. This percentage ranged from $3.5 \%$ to $24.1 \%$ in different age groups. The data on distribution of each trait - lifelong milk intake, only in childhood milk intake in different age groups are presented in Table 1 .
Variability in the distribution of lactose intolerance between age groups was found $(\mathrm{p}<0.01)$ (Table 1$)$. The irregular distribution by age groups of individuals with a first degree of parents exogamy was revealed $(\mathrm{p}<0.01)$.

In the group of patients aged of 30-39 years, the proportion of persons with lactose intolerance was 2.5 6 times higher than in others, while the proportion of individuals with the first degree of parents' exogamy was 1.4-2.5 times less than in other age groups (Table 1).

Table 1

Distribution of attitude regarding milk intake among different age groups

\begin{tabular}{|c|c|c|c|c|c|}
\hline \multirow{2}{*}{$\begin{array}{c}\text { Age range, } \\
\text { years }\end{array}$} & \multirow[b]{2}{*}{$\mathrm{N}$} & \multicolumn{3}{|c|}{ Milk intake, \% } & \multirow{2}{*}{$\begin{array}{l}\text { 1st degree } \\
\text { of parents } \\
\text { exogamy, \% }\end{array}$} \\
\hline & & $\begin{array}{l}\text { Life- } \\
\text { long }\end{array}$ & Never & $\begin{array}{l}\text { Only in } \\
\text { Childhood }\end{array}$ & \\
\hline $20-29$ & 136 & 69.1 & 7.4 & 23.5 & 24.3 \\
\hline $30-39$ & 79 & 46.8 & 24.1 & 29.1 & 15.4 \\
\hline $40-49$ & 140 & 70.0 & 9.3 & 20.7 & 30.0 \\
\hline $50-59$ & 77 & 79.2 & 7.8 & 13.0 & 31.2 \\
\hline $60-69$ & 103 & 76.7 & 4.9 & 18.4 & 28.7 \\
\hline $70-79$ & 85 & 74.5 & 4.7 & 17.9 & 38.6 \\
\hline \multicolumn{2}{|c|}{ Distribution, $p$} & $>0.05$ & $<0.01$ & $>0.05$ & $<0.01$ \\
\hline
\end{tabular}

Note: $N$ - number of patients studied, $p$-statistical significance

Since the literature widely discusses the effects of lactose on calcium metabolism, bone health and calcium bioavailability from alternative sources and the impact on bone health, we focused further activity on the study of the lactose tolerance/intolerance effect on the bone system pathologies and comorbidity.

In patients group allele frequencies were: $13910 \mathrm{~T}-$ $0.34,13910 \mathrm{C}-0.66,22018 \mathrm{~A}-0.35,22018 \mathrm{G}-0.65$. Genotypes distribution was $0 \%: 67.6 \%: 32.4 \%$ for TT:CT:CC and $2.9 \%: 64.7 \%: 32.4 \%$, for AA:GA:GG. Deviation from the Hardy-Weinberg equilibrium was observed $(p=0.027, p=0.050)$. When analyzed genotypes for both SNPs, we have revealed that the ratio CTAA:CTGA: CCGA:CCGG was $2.9 \%$ : $61.7 \%: 2.9 \%: 32.5 \%$. Group was not in Hardy-Weinberg equilibrium. There were no patients with the TTAA genotype.

The literature describes that a haplotype 13910T/22018A conferring lactase persistence, had a tightly clustered microsatellite allele distribution and showed lack of recombination [14]. According our results the linkage disequilibrium was estimated, D' $\left(\mathrm{r}^{2}\right)$ for SNPs analyzed were -0.209 (0.554).

A shift in the sex ratio in favor of the women was noted in the group of heterozygous patients - 1:2.6, among homozygotes patients $-1: 2.2$. The average age of patients with homozygous and heterozygous genotypes does not have a statistically significant difference.

A half of the patients had osteoporosis or osteopenia. The parameters BMD of CTGA patients were $4049.8 \pm 38.7$ and $4109.6 \pm 30.0$ for CCGG patients $(p=$ $=0,592$ ) (Table 2). A significant correlation between the 
number of low-functional alleles and the values of BMD of patients have not been revealed $(p=0.172)$.

Table 2

Patients characteristics with distribution of different genotypes by MCM6 gene

\begin{tabular}{|c|c|c|c|c|}
\hline \multirow[b]{2}{*}{ Trait } & \multicolumn{4}{|c|}{ Genotypes } \\
\hline & $\begin{array}{l}\text { CTGA } \\
(\mathrm{n}=21)\end{array}$ & $\begin{array}{l}\text { CCGA } \\
(\mathrm{n}=1)\end{array}$ & $\begin{array}{l}\text { CTAA } \\
(\mathrm{n}=1)\end{array}$ & $\begin{array}{l}\text { CCGG } \\
(\mathrm{n}=11)\end{array}$ \\
\hline \multirow{2}{*}{ Age, years old } & $61.9 \pm 3,5^{*}$ & 50 & 55 & \multirow{2}{*}{$70.7 \pm 4.3^{*}$} \\
\hline & \multicolumn{3}{|c|}{$61.0 \pm 3.2$} & \\
\hline \multirow[t]{2}{*}{$\mathrm{BMD}, \mathrm{m} / \mathrm{s}$} & $\begin{array}{c}4049.8 \pm \\
\pm 38.7^{*}\end{array}$ & 3961.0 & 3965.0 & \multirow{2}{*}{$\begin{array}{c}4109.6 \pm \\
\pm 30.0^{*}\end{array}$} \\
\hline & \multicolumn{3}{|c|}{$4042.2 \pm 35.6$} & \\
\hline Osteoporosis, $\%, \mathrm{n}$ & $23.8(5)$ & $0(0)$ & $0(0)$ & $0(0)$ \\
\hline Osteopenia, $\%, \mathrm{n}$ & $23.8(5)$ & $100(1)$ & $100(1)$ & $45.5(5)$ \\
\hline $\begin{array}{c}\text { All pathologies of } \\
\text { the digestive tract, } \\
\qquad \%, \mathrm{n}\end{array}$ & $52.4(11)$ & $0(0)$ & $0(0)$ & $45.5(5)$ \\
\hline $\begin{array}{l}\text { Gastritis, peptic } \\
\text { ulcer, duodenal } \\
\text { ulcer, stomach } \\
\text { cancer, } \%, n\end{array}$ & $52.4(11)$ & $0(0)$ & $0(0)$ & $18.2(2)$ \\
\hline $\begin{array}{c}\text { Appendectomy, } \\
\%, \mathrm{n}\end{array}$ & $28.6(6)^{* *}$ & $0(0)$ & $0(0)$ & $0(0)^{* *}$ \\
\hline
\end{tabular}

Note: $n$-patients number, ${ }^{*}$ - groups compared were CTGA and $C C G G$, ** - statistically significant difference, $p<0.001$

At the same time, all patients with osteoporosis had a CTGA genotype, average value of BMD was 3795.6 \pm 43.8 . Pathologies of the gastrointestinal tract, such as gastritis $(33.3 \%)$, peptic ulcer $(9.5 \%)$, duodenal ulcer $(9.5 \%)$ stomach cancer $(9.5 \%)$ and others, had patients with CTGA genotype (Table 2). Heterozygous genotypes significantly increase the risk of gastrointestinal pathology in patients fractures of the proximal femur $(\mathrm{OR}=5.0495 \%$ CI 1.01-25.04, $p<0,05) .28 .6 \%$ of heterozygous patients had a history of appendectomy, which requires further study.

\section{Discussion}

The study showed that lactose tolerance was found in $69.4 \%$ of Ukrainian patients, which corresponded the data on other European populations - French (0.71), Estonians (0.64), Polish (0.63) [15].

In the age group of 30-39 years, the proportion of persons with lactose intolerance was the highest. According to our results, in this group the lowest value of persons with the lowest parents' exogamy degree was noted. As we have shown earlier, parameters of persons exogamy degree may affect the frequency of genetic recombination [16].

The trend to assortative marriages increased inbreeding level. It results in decreased population diversity, increased number of similar loci in chromosomes during conjugation and therefore intensified recombination processes associated with chromosome rearrangements and reducing number of homozygotes. Increased exogamy de- gree is associated with increased D' $\left(\mathrm{r}^{2}\right)$ in loci. According to researchers, usually T/A $(\mathrm{C} / \mathrm{G})$ haplotype showed lack of recombination within a $61.4-\mathrm{kb}$ region encompassing 3 microsatellite markers, suggesting a unique, relatively recent origin. Two alleles uniquely mark a common ( $\sim 77 \%)$ haplotype that extends largely undisrupted. In our sample of patients this measure was $55.4 \%$.

Since the recombination process creates the prerequisites for multifactorial pathology, it seems relevant to analyze the genetic characteristics of patients with pathologies of the skeletal system associated with the exchange of lactose by the general metabolism. It is also important to consider the associations of decrease in bone mineral density and pathologies of digestive tract.

It should be noted that our patients with a heterozygous genotype and more severe manifestations of multifactorial pathology consumed lactose-containing products during the periods of their lives. It is important to clarify that lactose is not only contained in milk and all milk products but may be added as an ingredient to many different foods and beverages.

In our study no osteoporosis in heterozygotes patients with lactose intolerance, was noted, in contrast to the group of heterozygotes $(23.8 \%)$. Patients with bone fractures and osteoporosis have gastritis, peptic ulcer, stomach cancer and others. Probably, the assimilation of lactose-containing products could be considered as a risk factor for a decrease in bone mineral density and disorders of the gastrointestinal tract. The results we obtained are consistent with the data presented by some other authors. Iacone R. et al. (2018) [17] noticed that metabolic acidosis and metabolic bone disease are frequent complications in patients on parenteral nutrition. According to Baranov V. S. (2009) [18], excessive consumption of animal-derived proteins and cereals has contributed to the enhancement of calciuria and the secondary negative calcium balance. High protein intake increases calcium excretion and has negative affect on level of calcium in organism. However, other research suggests that high protein intake also increases intestinal calcium absorption, effectively offsetting its effect on calcium excretion, so whole body calcium retention remains unchanged.

We did not obtain statistically significant differences in some characteristics between groups of heterozygotes and homozygotes due to the sample size. However, the trend to improvement BMD, the pathology development age, the severity, and the comorbidity in homozygotes with lactose intolerance demonstrate that the rejection of dairy and other lactose-containing products is not critical for the pathological conditions prevention. These data confirm our research results obtained on model objects [19]: pregnancy and lactation are not associated with reduced bone mineral density in a balanced and high-grade diet of cows.

In our study, stomach cancer among other gastrointestinal pathologies was noted in heterozygous patients consumed dairy products during periods of their life. Larsson S. C. et al. [20] showed that generous intake of dairy foods may increase the likelihood of developing ovarian cancer. The main finding of researchers was that the risks 
of lung, breast, and ovarian cancers were significantly decreased among individuals with lactose intolerance, whereas the incidences in their siblings and parents were similar compared with the general population.

Thus the study of metabolism genetic aspects creates the basis for personified therapy, nutritional and genetic safety of human.

Study limitations. Our research was restricted to include not only patients of Communal enterprise of health care «Kharkiv clinical multy-field hospital No. 17 of plant named by Malyshev», but also healthy participants.

Prospects for further researches. Future study should describe how diet education in nation level can influence to numerosity of cases with femoral neck fracture.

\section{Conclusions}

The study showed that lactose tolerance was found in $69.4 \%$ of Ukrainians, which was consistent with data on other European populations. All patients with osteoporosis had a genotype CTGA, average value of BMD was 3795.6 \pm 43.8. CTGA-patients had following gastrointestinal tract disorders: gastritis (33.3\%), peptic ulcer (9.5\%), duodenal ulcer $(9.5 \%)$, and stomach cancer $(9.5 \%)$. Heterozygous genotypes significantly increase five times the risk of gastrointestinal pathology in patients with fractures of the proximal femur.

\section{Conflicts of interest}

The authors declare that they have no conflicts of interest.

\section{References}

1. Kettunen, J., Silander, K., Saarela, O., Amin, N., Muller, M., Timpson, N. et. al. (2009). European lactase persistence genotype shows evidence of association with increase in body mass index. Human Molecular Genetics, 19 (6), 1129-1136. doi: http:// doi.org/10.1093/hmg/ddp561

2. Bonjour, J.-P. (2013). Nutritional disturbance in acid-base balance and osteoporosis: a hypothesis that disregards the essential homeostatic role of the kidney. British Journal of Nutrition, 110 (7), 1168-1177. doi: http://doi.org/10.1017/s0007 114513000962

3. Enattah, N. S., Sahi, T., Savilahti, E., Terwilliger, J. D., Peltonen, L., Järvelä, I. (2002). Identification of a variant associated with adult-type hypolactasia. Nature Genetics, 30 (2), 233-237. doi: http://doi.org/10.1038/ng826

4. Ji, J., Sundquist, J., Sundquist, K. (2014). Lactose intolerance and risk of lung, breast and ovarian cancers: aetiological clues from a population-based study in Sweden. British Journal of Cancer, 112 (1), 149-152. doi: http://doi.org/10.1038/bjc.2014.544

5. Somekawa, Y., Chiguchi, M., Ishibashi, T., Aso, T. (2001). Soy intake related to menopausal symptoms, serum lipids, and bone mineral density in postmenopausal Japanese women. Obstetrics \& Gynecology, 97 (1), 109-115. doi: http://doi.org/10.1016/ s0029-7844(00)01080-2

6. Wagh, K., Bhatia, A., Alexe, G., Reddy, A., Ravikumar, V., Seiler, M. et. al. (2012). Lactase Persistence and Lipid Pathway Selection in the Maasai. PLoS ONE, 7 (9), e44751. doi: http://doi.org/10.1371/journal.pone.0044751

7. Albuquerque, D., Nóbrega, C., Manco, L. (2013). The lactase persistence -13910C $>$ T polymorphism shows indication of association with abdominal obesity among Portuguese children. Acta Paediatrica, 102 (4), e153-e157. doi: http://doi.org/10.1111/ apa.12134

8. Guo, J., Astrup, A., Lovegrove, J. A., Gijsbers, L., Givens, D. I., Soedamah-Muthu, S. S. (2017). Milk and dairy consumption and risk of cardiovascular diseases and all-cause mortality: dose-response meta-analysis of prospective cohort studies. European Journal of Epidemiology, 32 (4), 269-287. doi: http://doi.org/10.1007/s10654-017-0243-1

9. Fenton, T. R., Tough, S. C., Lyon, A. W., Eliasziw, M., Hanley, D. A. (2011). Causal assessment of dietary acid load and bone disease: a systematic review \& meta-analysis applying Hill's epidemiologic criteria for causality. Nutrition Journal, 10(1). doi: http:// doi.org/10.1186/1475-2891-10-41

10. Shams-White, M. M., Chung, M., Fu, Z., Insogna, K. L., Karlsen, M. C., LeBoff, M. S. et. al. (2018). Animal versus plant protein and adult bone health: A systematic review and meta-analysis from the National Osteoporosis Foundation. PLOS ONE, 13 (2), e0192459. doi: http://doi.org/10.1371/journal.pone.0192459

11. Kalchenko, A., Babalyan, V., Hurbanova, T., Maznyakov, S. (2016). Surgical treatment of proximal femur osteoporotic fractures (literature review). Orthopaedics, Traumatology and Prosthetics, 2, 111-119. doi: http://doi.org/10.15674/0030598720162111-119

12. Rocha-Braz, M. G. M., Ferraz-de-Souza, B. (2016). Genetics of osteoporosis: searching for candidate genes for bone fragility. Archives of Endocrinology and Metabolism, 60 (4), 391-401. doi: http://doi.org/10.1590/2359-3997000000178

13. Kuchay, R. A. H., Anwar, M., Thapa, B. R., Mahmood, A., Mahmood, S. (2012). Correlation of G/A -22018 single-nucleotide polymorphism with lactase activity and its usefulness in improving the diagnosis of adult-type hypolactasia among North Indian children. Genes \& Nutrition, 8 (1), 145-151. doi: http://doi.org/10.1007/s12263-012-0305-7

14. Coelho, M., Luiselli, D., Bertorelle, G., Lopes, A. I., Seixas, S., Destro-Bisol, G., Rocha, J. (2005). Microsatellite variation and evolution of human lactase persistence. Human Genetics, 117 (4), 329-339. doi: http://doi.org/10.1007/s00439-005-1322-z

15. Hodges, J., Cao, S., Cladis, D., Weaver, C. (2019). Lactose Intolerance and Bone Health: The Challenge of Ensuring Adequate Calcium Intake. Nutrients, 11 (4), 718. doi: http://doi.org/10.3390/nu11040718 
16. Fedota, O. M., Babalian, V. O., Borozenets, V. V., Mazniakov, S. M., Puzik, N. G. (2019). Lactose intolerance and its association with the exogamy degree among the population of eastern Ukraine. Faktori Eksperimental'noi Evolucii Organizmiv, 24, $249-253$. doi: http://doi.org/10.7124/feeo.v24.1110

17. Iacone, R., Scanzano, C., D’Isanto, A., Vitalone, A., Frangipane, I., D’Angeli, M. et. al. (2018). Prediction of Renal Acid Load in Adult Patients on Parenteral Nutrition. Pharmaceutics, 10 (2). doi: http://doi.org/10.3390/pharmaceutics 10020043

18. Baranov, V. S. (2009). Geneticpassport-the basis of individual and predictive medicine. Saint-Petersburg, 528.

19. Fedota, O. M., Babalian, V. O., Mitiohlo, L. V., Mazniakov, S. M., Valilshchikov, M. V., Tyzhnenko, T. V., Ruban S. Yu. (2017). Bone mineral density in evaluation the productive traits and reproductive health of dairy cows. Journal for veterinary medicine, biotechnology and biosafety, 3 (4), 16-22. Available at: http://nbuv.gov.ua/UJRN/jvmbb_2017_3_4_6

20. Larsson, S. C., Orsini, N., Wolk, A. (2006). Milk, milk products and lactose intake and ovarian cancer risk: A meta-analysis of epidemiological studies. International Journal of Cancer, 118 (2), 431-441. doi: http://doi.org/10.1002/ijc.21305

Received date 20.05.2020

Accepted date 16.06.2020

Published date 31.07.2020

Olena Fedota, Doctor of Biological Sciences, Professor, Department of Obstetrics and Gynecology, V. N. Karazin Kharkiv National University, Svobody sq., 4, Kharkiv, Ukraine, 61022

E-mail: omfedota@karazin.ua

Volodymyr Babalian, PhD, Associate Professor, Department of Traumatology, Anesthesiology and Military Surgery, Kharkiv Medical Academy of Postgraduate Education, Amosova str., 58, Kharkiv, Ukraine, 61176 E-mail: babalyanvladimir@gmail.com

Victoria Borozenets, Assistant, Department of General and Clinical Pathology, V. N. Karazin Kharkiv National University, Svobody sq., 4, Kharkiv, Ukraine, 61022

E-mail: Vikaborozenets1984@gmail.com

Nina Puzik, PhD, Department of Medical Biology, Kharkiv National Medical University, Nauky ave., 4, Kharkiv, Ukraine, 61022

E-mail: n.g.lysenko@gmail.com 